\title{
Physico-chemical and electrostatic surface characterisation of mica mineral and its applicability on the adsorption of Safranin Orange and Reactive Black 5 dyes
}

\section{Anna Carla Ribeiro, Murilo Barbosa de Andrade, Heloise Beatriz Quesada, Laiza Bergamasco Beltran, Rosângela Bergamasco, Maria Madalena Calado Santos Sobral da Fonseca \& Elizabeth da Costa Neves Fernandes de Almeida Duarte}

To cite this article: Anna Carla Ribeiro, Murilo Barbosa de Andrade, Heloise Beatriz Quesada, Laiza Bergamasco Beltran, Rosângela Bergamasco, Maria Madalena Calado Santos Sobral da Fonseca \& Elizabeth da Costa Neves Fernandes de Almeida Duarte (2021): Physicochemical and electrostatic surface characterisation of mica mineral and its applicability on the adsorption of Safranin Orange and Reactive Black 5 dyes, Environmental Technology, DOI: 10.1080/09593330.2021.1934562

To link to this article: https://doi.org/10.1080/09593330.2021.1934562

Published online: 09 Sep 2021.

Џ Article views: 29

曲 Published online:09 sep 2021.

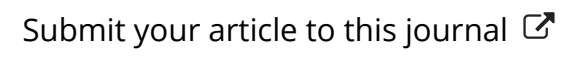
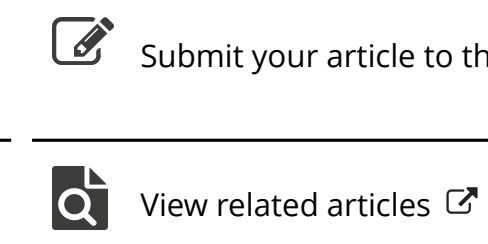

View Crossmark data $\longleftarrow$ 


\title{
Physico-chemical and electrostatic surface characterisation of mica mineral and its applicability on the adsorption of Safranin Orange and Reactive Black 5 dyes
}

\author{
Anna Carla Ribeiro ${ }^{a}$, Murilo Barbosa de Andrade ${ }^{b}$, Heloise Beatriz Quesada $\mathbb{C}^{b}$, Laiza Bergamasco Beltran ${ }^{c}$, \\ Rosângela Bergamasco ${ }^{b}$, Maria Madalena Calado Santos Sobral da Fonseca ${ }^{d}$ and Elizabeth da Costa Neves \\ Fernandes de Almeida Duarte ${ }^{a}$

\begin{abstract}
aLEAF - Linking Landscape, Environment, Agriculture and Food, Universidade de Lisboa - Instituto Superior de Agronomia, Lisbon, Portugal; bepartment of Chemical Engineering, Universidade Estadual de Maringá, Maringá/Paraná, Brazil; 'Graduate Program in Food Sciences, Universidade Estadual de Maringá, Maringá/Paraná, Brazil; ${ }^{d}$ CEF - Forest Research Centre, Universidade de Lisboa - Instituto Superior de Agronomia, Lisbon, Portugal
\end{abstract}

\section{ABSTRACT}

The combined approach of specific surface area (SSA), porosity, microprobe analysis (EMPA), transmission electron microscopy (TEM), scanning electron microscopy (SEM) equipped with EDX and infrared spectroscopy (FTIR) provided the mica mineral physico-chemical and morphological characterisation. The electrostatic surface properties were assessed through the determination of the Point of Zero Charge $\left(\mathrm{pH}_{\mathrm{PzC}}\right)$ by the drift method and the electrokinetic mica mineral features represented by the Isoelectric Point $\left(\mathrm{pH}_{\mathrm{IEP}}\right)$ which was carried out through zeta potential measurements. Adsorption tests were performed to correlate the surface charge behaviour of the mica mineral and its influence on the adsorption efficiency of two different dyes, namely: Safranin Orange (SO), as a cationic dye and Reactive Black 5 (RB5), as an anionic dye. The higher adsorption capacity SO dye was observed at $\mathrm{pH} 9$ and achieved almost $83 \%$ of removal, while RB5 dye adsorption on mica surface had the highest result, about $45 \%$ of removal efficiency, on $\mathrm{pH}$ of 3 . In both cases, the main mechanism identified that drove this results is the electrostatic force of attraction between the adsorbent edge surface charge $(\mathrm{pH}$ dependent) and the ionic nature (anionic or cationic) of the pollutant dyes particles. The preliminary adsorption experiments demonstrated that the raw grounded mica mineral has a greater potential associated with its application on cationic dye removal in wastewater. The present study aimed to detail the main characteristics of the mica mineral in order to evaluate the potential use of such mineral residues in the removal efficiency of contaminated wastewater.
ARTICLE HISTORY

Received 1 August 2020

Accepted 10 May 2021

KEYWORDS

Mica mineral; electrostatic properties; adsorption; Safranin Orange; Reactive Black 5

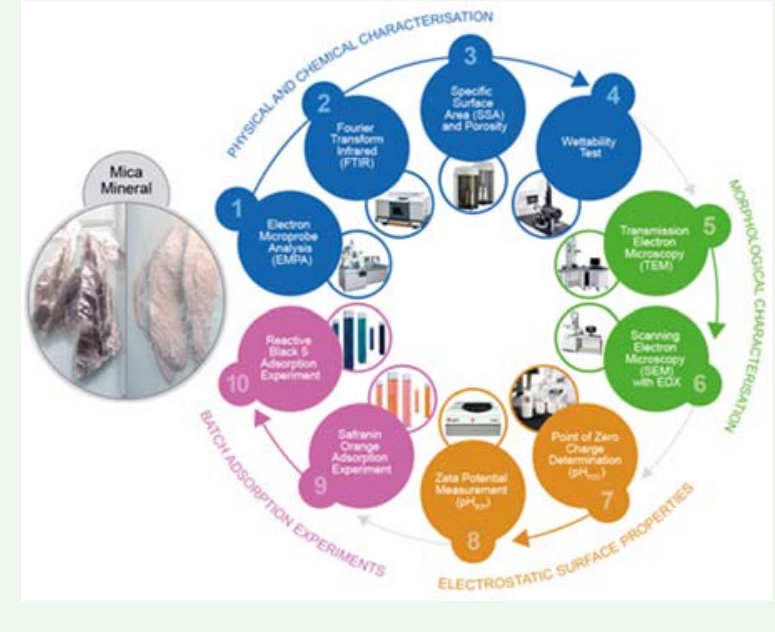

\section{Introduction}

During the last century, the water bodies have been facing a huge negative pressure relationed with the great scale industries development and the increasing products and services demands. The disposal of untreated industrial effluents directly into nature has been affecting the quality and safety of fresh and groundwater ecosystems. Thus, in the last decades, the preservation of the water resources became a global concern and captured the scientific community's attention [1,2]. 
Pigments and dyes, in particular, are complex chemical substances that are widely used as colourising agents in many industrialisation processes (textile, paper and plastic). There are about 100,000 types of dyes commercially available in the market and its production reaches more than $7 \times 10^{5}$ tonnes per year, which $2 \%$ of them are directly discharged into the water bodies. The release of such massive amount of contaminated wastewater has serious environmental consequences and human health hazard due the non-biodegradable feature and carcinogenic action, which causes allergies, dermatitis, skin irritation and organs dysfunctions [2-4].

Briefly, dyes are classified in natural and synthetic ones, which was developed in order to sustain the global demand mainly in the fabrics and textile industries. The second group is also divided into ionic dyes (cationic and anionic) and non-ionic dyes (vap and dispersive) [2].

Among all of the dyes removal techniques (coagulation/precipitation, membrane filtration, electrochemical and ion exchange), the adsorption technology is evaluated as the most attractive due its removal efficiency achieved, low implementation cost and operation simplicity. Furthermore, non-conventional alternative adsorbents has been extensively explored by several researchers diversifying the options and optimising the adsorption applicability. Many natural materials such as geomaterials (minerals, rocks and soils) and biomass (agriculture wastes) have been successfully used on this field [1-5].

According to the literature, the primary or secondary (clay minerals, which can be found in the clay fraction of the soil) phyllosilicate minerals have been investigated for pollutants adsorption applications such as, pesticides, an ample range of heavy metal and dyes [4-14].

The layered lattice structure of mica mineral is disposed in a structure classified as 2:1, where an octahedral sheet is in the middle linked by weak van der Waal force to the other two tetrahedral units by sharing its edges $[15,16]$.

Its structure feature provides a large surface area associated with high ion-exchange capacity, which makes such minerals possess a huge potential applicability on adsorption fields. Besides that, with cleavage, two reactive planes are formed: basal and edges, with different chemical specifications which need to be taken into account carefully, because it requires different characterisation methods. The $\mathrm{pH}$ is an intrinsic parameter related to the proton activity in the suspension system of charged colloidal particles $[6,8,13,17,18]$.

Some approaches also investigate chemical modifications on the mineral surface, such as pre- treatment/activation or even its complete synthesis named layered double hydroxides (LDHs), which propose an improvement in the adsorption efficiency [8,19-22].

Moreover, Meena et al. [23] and Basak and Biswas [24] report a huge quantity of waste mica minerals (biotite and mainly muscovite) originating from raw explored mica mines in Jharkhand district in India, where the largest mica deposit in the world is located. Mica is used as a potassium source for plant needs in agriculture, but about $75 \%$ of the mineral extraction is not used for this purpose due to its low content of potassium and it is dumped in the soil. These residues accumulate on the ground for long periods of time without receiving any type of treatment, generating a huge environmental impact for the surrounding community of that area. From a more sustainable point of view, such material could be addressed for study and posterior use in adsorption.

Therefore, the evaluation of the potential use of mica mineral residues in contaminant removal is a challenge, as part of the incentive to promote a circular economy, whose main premise is the valuation of eventually waste materials (mica minerals) that, according to the linear economy approach, are classified as residues. In addition, there has been noted that few studies are used to observe the mineral behaviour facing pollutants with different ionic nature with variation of $\mathrm{pH}$ solution on adsorption tests.

The present study aimed to realise a combined approach of physical, chemical, morphological and electrostatic surface properties characterisation of the mica mineral. Adsorption tests were performed to correlate the surface charge behaviour of the mica mineral in range of $\mathrm{pH}(3,5,7$ and 9) and its influence on the adsorption efficiency of two different dyes, namely: Safranin Orange (SO), as a cationic dye and Reactive Black 5 (RB5), as an anionic dye.

\section{Materials and methods}

The mica mineral used in this study originated from LP Minerais Company located in São Paulo, Brazil. Figure 1 shows the mineral as it was acquired. The pieces with an average dimension of $15 \times 6 \mathrm{~cm}$ were used for the electron microprobe analysis (EMPA).

The remaining mineral $(\sim 1 \mathrm{~kg})$ was broken by hand into chunks and crushed using a Retsch high-speed planetary mill at $50 \mathrm{cycle} / \mathrm{second}$ during one hour. The fraction lower than $<250 \mu \mathrm{m}$ was separated using a 60 mesh steel sieve as shown in Figure 2. The ground micaceous mineral was used for all the characterisation analysis described below. 


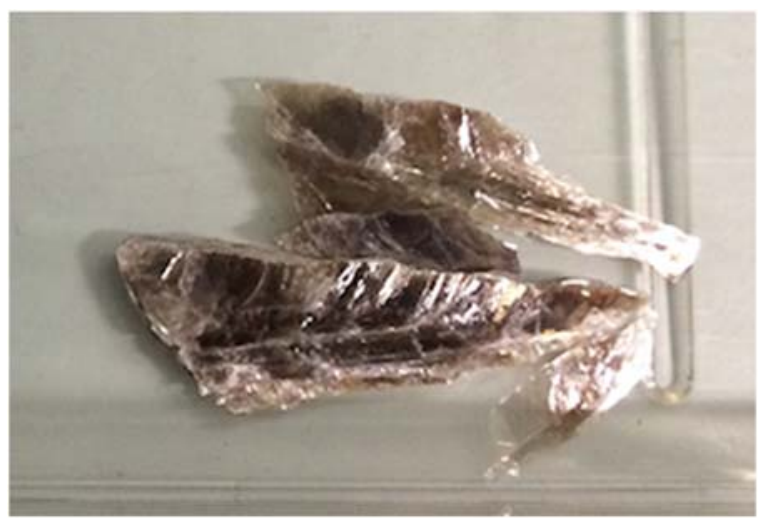

Figure 1. Mica mineral pieces used for electron microprobe analysis.

\subsection{Physical and chemical characterisation}

\section{Electron microprobe analysis (EMPA)}

The bulk chemical composition of the mica mineral sheet was characterised by electron microprobe analysis (EMPA, Jeol JXA-8200) using the average of 10 scanning points. The lithium and hydrogen contents were not measured, but they were calculated from the stoichiometry of the mica. They lack, therefore, confirmation by another technique, particularly in the case of lithium whose value should be taken only as an indicator.

\section{Particle size distribution study}

In order to promote the desegregation of the mica mineral grain, a sample containing $5 \mathrm{mg}$ of the powder of the micaceous mineral was mixed with 30
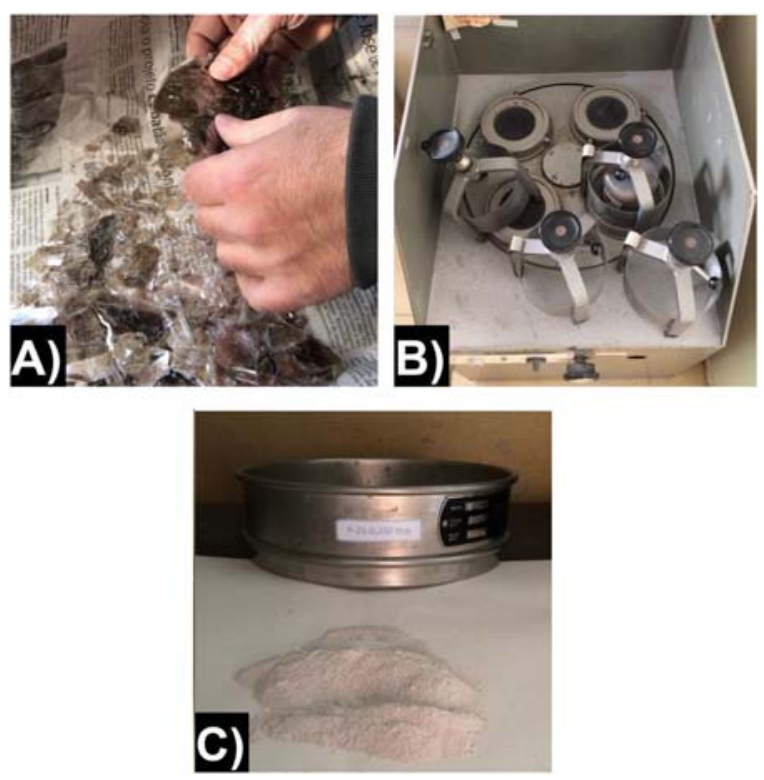

Figure 2. Manual breaking (a), milling (b) and sieving (c) process of mica mineral. $\mathrm{ml}$ of distilled water to be submitted to the ultrasonication process (Quimis ultrasonic bath) for two hours. This process generates implosive forces that cause the complete withdrawal of the particles, permitting them to observe the size of a singular one in the dispersive solution.

The sample was inserted into the electrophoretic light scattering equipment (DLE) and analysed using particle analyser software Delsa Nano UI version 3.73. (function Size $1203 \mathrm{AB})$.

\section{Fourier transform infrared (FTIR) spectroscopy}

The mica mineral powder was characterised by infrared spectroscopy (FTIR) using a Varian 1000 FTIR spectrometer (Scimitar series) with spectra that cover the region of $4000-350 \mathrm{~cm}^{-1}$ at room temperature. The sample was prepared in pellets in the ratio of $2 \%$ to $98 \%$ of potassium bromide $(\mathrm{KBr})$.

\section{Specific surface area (SSA) and porosity}

The specific surface area and the porous structure of the mica mineral were determined through the phenomenon of $\mathrm{N}_{2}$ adsorption (Tristar II 3020, Micromeritics Instrument (o., USA), where the gas molecules occupy both the external surface area and also penetrate into capillaries. The mathematical equations used to interpret such results are Brunauer-Emmett-Teller (BET) and Barrett-Joyner-Halenda (BJH) methods for specific surface area and porosity, respectively.

\section{Wettability test}

The wettability of the mica was performed by using the static contact angle measuring equipment (Tantec, model Cam-Micro) at room temperature. The adhesion ability of the water drop on the mica surface was also observed in two states: in a piece of raw mica sheet and in a tablet made of grounded mica.

\subsection{Morphological characterisation}

\section{Transmission electron microscopy (TEM)}

The sample preparation involving a suspension containing $5 \mathrm{mg}$ of micaceous mineral with $20 \mathrm{ml}$ of ethyl alcohol $96^{\circ}$ was submitted to the ultrasonication process for $1 \mathrm{~h}$. Then, two drops of this solution were deposited on the analysis grid $\mathrm{Cu}$ sample coated with carbon film (CF200-Cu, EMS), and it was put into the drying oven regulated at $60^{\circ} \mathrm{C}$ for $24 \mathrm{~h}$.

The morphology was examined using a $120 \mathrm{kV}$ JEOL JEM-1400 transmission electron microscope (TEM). 


\section{Scanning electron microscopy (SEM) equipped with EDX}

For the elemental chemical characterisation, the powdered micaceous mineral was prepared by its deposition on a double-sided carbon tape to be metallised with gold.

After that, the sample was imaged using a field emission gun scanning electron microscope (JEOL 840-A) at an acceleration voltage of $15 \mathrm{kV}$ and equipped with energy dispersive $X$-ray spectrometry (EDX) support software (Oxford Instruments Nanotechnology Tools Ltd).

\subsection{Electrostatic surface properties}

\section{Point of Zero Charge determination}

The determination of the Point of Zero Charge was realised by the drift method as previously described by Balouch et al. [25] and Khan and Sarwar [26].

The $\mathrm{NaCl}$ electrolyte solution $(0.01 \mathrm{M}) \mathrm{pH}$ was registered (4.67) and was adjusted to a value raging 2.0 to 10.0 using $0.5 \mathrm{M} \mathrm{HCl}$ with $37 \%$ of purity $(\mathrm{pH}=1.07)$ and $0.5 \mathrm{M} \mathrm{NaOH}$ with $99 \%$ of purity $(\mathrm{pH}=14.32)$.

Thus the samples were analysed, in triplicate mode, by mixing $0.5 \mathrm{~g}$ of the ground micaceous mineral with an aliquot of $20 \mathrm{ml}$ of each $\mathrm{pH}$ solution. The 27 samples were shaken continuously at $150 \mathrm{rpm}$ during $24 \mathrm{~h}$ at room temperature. At the end of the time, the final $\mathrm{pH}$ in each vial was measured using a Thermo Scientific meter (Orin 3-Star model). Before using the equipment, the $\mathrm{pH}$ electrode was calibrated with buffer solutions of $\mathrm{pH} 4.05,7.04$ and 10.05 .

\section{Zeta potential}

The suspension was prepared using $10 \mathrm{mg}$ of micaceous mineral powder in $20 \mathrm{~mL}$ of distilled water, and the $\mathrm{pH}$ adjustment was done using $\mathrm{NaOH}(0.1$ and $1 \mathrm{M})$ and $\mathrm{HCl}(0.1$ and $1 \mathrm{M})$ solutions.

The zeta potential measurement was carried out, in triplicate, using electrophoretic light scattering analysis in order to observe the mobility of the micaceous mineral charged particles when submitted into an electric field applied during 15 min from the Doppler shift of scattered light in Beckman Coulter Delsa ${ }^{\mathrm{TM}}$ Nano Zeta
Potential software Delsa Nano UI version 3.73 (function Zeta 1203). The analysis contemplated the $\mathrm{pH}$ value variation from 2 to 12 .

\subsection{Batch adsorption experiments}

In order to understand the electrical behaviour of the mica mineral in adsorption processes, batch experiments were carried out using $100 \mathrm{~mL}$ hermetic flasks in a shaker (Tecnal, TE-4200) at $150 \mathrm{rpm}$. Briefly, $0.05 \mathrm{~g}$ of grounded mica mineral was put in contact with 20 $\mathrm{mL}$ of $10 \mathrm{mg} \mathrm{L}^{-1}$ of adsorbate solution, agitated for 24 $\mathrm{h}$ at $25^{\circ} \mathrm{C}$. The adsorbates were cationic (Safranin Orange, SO) and anionic (Reactive Black 5, RB5) dyes, whose $\mathrm{pH}$ was adjusted to $3,5,7$ and 9 .

After the contact time, the samples were filtered through a $0.45 \mathrm{~mm}$ cellulose acetate membrane (Unifi) and the final concentration was determined in a UVvisible spectrophotometer (Hach DR 5000).

The parameter analysed was the adsorption capacity, calculated as Equation (1):

$$
q_{e}=\frac{\left(C_{i}-C_{f}\right) \cdot V}{m}
$$

where $C_{i}$ and $C_{f}$ are the initial and final adsorbate concentration, respectively $\left(\mathrm{mg} \mathrm{L}^{-1}\right), V$ represents the volume solution (L) and $\mathrm{m}$ represents the mass of grounded mica mineral $(\mathrm{g})$.

\section{Results and discussion}

\subsection{Physical and chemical characterisation}

\section{Electron microprobe analysis (EMPA)}

The results of electron microprobe analysis of the micaceous material chemical composition are shown in Tables 1 and 2 . The results for the oxides are in mass percentages, and the results of the groups are in the number of cations per unit of formula.

The mica group is composed of 37 different minerals, and the physical appearance of the raw micaceous mineral is predominantly composed of a mixture of two colours such as greenish off-white and some darker parts. The mineral surface also has a visible

Table 1. Results of electron microprobe analysis for the chemical components present in the mica mineral.

\begin{tabular}{|c|c|c|c|c|c|}
\hline Compound & Average (\%) & Standard deviation & Compound & Average (\%) & Standard deviation \\
\hline $\mathrm{SiO}_{2}$ & 46.6653 & 0.3359 & $\mathrm{MgO}$ & 0.5861 & 0.0128 \\
\hline $\mathrm{Al}_{2} \mathrm{O}_{3}$ & 31.3463 & 0.2034 & $\mathrm{~F}^{-}$ & 0.3393 & 0.1058 \\
\hline $\mathrm{K}_{2} \mathrm{O}$ & 10.7974 & 0.0468 & $\mathrm{Cr}_{2} \mathrm{O}_{3}$ & 0.0644 & 0.0235 \\
\hline $\mathrm{FeO}$ & 3.6180 & 0.1842 & $\mathrm{MnO}$ & 0.0536 & 0.0261 \\
\hline $\mathrm{Li}_{2} \mathrm{O}$ & 1.7681 & 0.5479 & $\mathrm{BaO}$ & 0.0184 & 0.0218 \\
\hline $\mathrm{TiO}_{2}$ & 0.7713 & 0.0248 & $\mathrm{CaO}$ & 0.0076 & 0.0118 \\
\hline \multirow[t]{2}{*}{$\mathrm{Na}_{2} \mathrm{O}$} & 0.6237 & 0.0222 & $\mathrm{Cl}^{-}$ & 0.0067 & 0.0086 \\
\hline & & & $\mathrm{H}_{2} \mathrm{O}$ & 4.3347 & 0.0557 \\
\hline
\end{tabular}


Table 2. Results of the microprobe analysis for the number of cations and anions present in the micaceous mineral.

\begin{tabular}{llcc}
\hline Group & Compound & Average (\%) & Standard deviation \\
\hline $\mathrm{T}$ & $\mathrm{Si}^{4+}$ & 3.1113 & 0.0289 \\
& $\mathrm{Al}^{3+}$ & 0.8887 & 0.0289 \\
$\mathrm{M}$ & $\mathrm{Total}^{3+}$ & 4.0000 & 0.0000 \\
& $\mathrm{Al}^{3+}$ & 1.5745 & 0.0432 \\
& $\mathrm{Fe}^{2+}$ & 0.2017 & 0.0099 \\
& $\mathrm{Mg}^{2+}$ & 0.0583 & 0.0014 \\
& $\mathrm{Li}^{+}$ & 0.4734 & 0.1452 \\
$\mathrm{~T}$ & $\mathrm{Total}^{+}$ & 2.3529 & 0.1070 \\
& $\mathrm{~K}^{+}$ & 0.9184 & 0.0028 \\
& $\mathrm{Na}^{+}$ & 0.0806 & 0.0026 \\
$\mathrm{~A}$ & $\mathrm{Total}^{+}$ & 1.0000 & 0.0000 \\
& $\mathrm{OH}^{-}$ & 1.9277 & 0.0221 \\
& $\mathrm{~F}^{-}$ & 0.0716 & 0.0224 \\
& Total & 2.0000 & 0.0000 \\
\hline
\end{tabular}

shining lustre. The differentiation between them is due to the variety of geological factors that are involved in their formation. However, the most common are muscovite mica and biotite mica [27-29].

The chemical constitution of the mica mineral sample analysed is dominated by $\mathrm{SiO}_{2}$ (46.66\%), $\mathrm{Al}_{2} \mathrm{O}_{3}$ (31.35\%) and $\mathrm{K}_{2} \mathrm{O}(10.80 \%)$ and followed by smaller amounts of $\mathrm{FeO}(3.62 \%)$ and $\mathrm{Li}_{2} \mathrm{O}(1.79 \%)$, which can be found in Tables 1 and 2 as results of EMPA analysis and in the EDX spectrum data shown in Figure 6(c), as well as in many other mineralogical characterisation works in the literature [13,27-30].

The chemical elements present in mica constitution have been explored in different environmental applications. The potassium has to be extracted and used as a nutrient source for agriculture, since the available stock has become depleted in many parts of the world due to the intense demand. The same happens for the lithium recovery from mica minerals that has also received considerable attention as a secondary and economically feasible raw material source to supplement the current industrial demand. The lamellar and flat structure of mica minerals has been extensively explored in the nanotechnology field as a base substrate for graphene imaging, for instance $[27,31,32]$.

\section{Particle size distribution study}

The particle size distribution study reveals, in Table 3, that the average size of the mica grain is $750.4 \mathrm{~nm}$ with standard deviation of $106 \mathrm{~nm}$ and the coefficient of variation of 0.141 .

The grain geometry plays a crucial role due to the substantial increment that it can provide to the total

Table 3. Result of particle size distribution study.

\begin{tabular}{lccc}
\hline \multicolumn{4}{c}{ Particle size $(\mathrm{nm})$} \\
\hline 1 & 2 & 3 & Average \\
\hline 862.6 & 651.4 & 737.1 & 750.4 \\
\hline
\end{tabular}

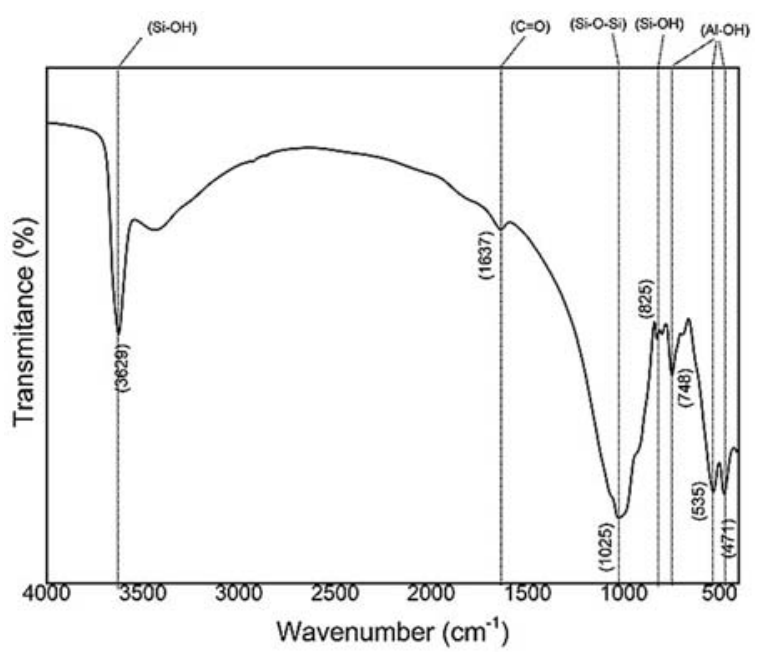

Figure 3. FTIR spectrum of grounded mica mineral.

surface area, in particular the edge surface, which is strongly reactive [33].

\section{FTIR analysis}

The mineralogy of the mica samples was also investigated by Fourier transform infrared (FTIR) spectroscopy, and the results are presented in Figure 3.

This analysis is a very useful tool for acquiring the most fundamental molecular vibration spectrum of the mineral, since its mid-infrared absorbance bands of each component are located in a range of 4000 and $400 \mathrm{~cm}^{-1}[34,35]$.

The principal elements are arranged in bonds inside the phyllosilicate structure, and Table 4 shows the basic type of these bridging bonds [36].

According to the literature, the $\mathrm{OH}$ stretching vibration is typically in the range of $3200-3750 \mathrm{~cm}^{-1}$, and it is easily noticed in Figure 4 through the medium intensity band produced due to the $\mathrm{Si}-\mathrm{OH}$ group. However, a second but softer vibration on the $825 \mathrm{~cm}^{-1}$ region is also observed. This may be related to the silicate layer. The spectrum peak seen in the absorption region of about

Table 4. Types of bridging ligations in phyllosilicate mineral. Source: [36].

\begin{tabular}{lccccc}
\hline $\begin{array}{l}\text { Element } \\
\text { (coordination) }\end{array}$ & $\mathrm{Si}$ & $\mathrm{Al}_{(\mathrm{T})}$ & $\mathrm{Al}_{(\mathrm{O})}$ & $\mathrm{Mg}_{(\mathrm{O})}$ & $\mathrm{Fe}_{(\mathrm{O})}$ \\
\hline $\mathrm{Si}_{(\mathrm{T})}$ & $\mathrm{Si}-\mathrm{O}-$ & $\mathrm{Si}-\mathrm{O}-\mathrm{Al}_{(\mathrm{T})}$ & $\mathrm{Si}-\mathrm{O}-\mathrm{Al}_{(\mathrm{O})}$ & $\mathrm{Si}-\mathrm{O}-\mathrm{Mg}_{(\mathrm{O})}$ & $\mathrm{Si}-\mathrm{O}-\mathrm{Fe}_{(\mathrm{O})}$ \\
& $\mathrm{Si}$ & & & & \\
$\mathrm{Al}_{(\mathrm{T})}$ & & $\mathrm{Al}_{(\mathrm{T})}-\mathrm{O}-$ & $\mathrm{Al}_{(\mathrm{T})}-\mathrm{O}-$ & $\mathrm{Al}_{(\mathrm{T})}-\mathrm{O}-$ & $\mathrm{Al}_{(\mathrm{T})}-\mathrm{O}-$ \\
& & $\mathrm{Al}_{(\mathrm{T})}$ & $\mathrm{Al}_{(\mathrm{O})}$ & $\mathrm{Mg}_{(\mathrm{O})}$ & $\mathrm{Fe}_{(\mathrm{O})}$ \\
$\mathrm{Al}_{(\mathrm{O})}$ & & & $\mathrm{Al}_{(\mathrm{O})}-\mathrm{OH}-$ & $\mathrm{Al}_{(\mathrm{O})}-\mathrm{O}-$ & $\mathrm{Al}_{(\mathrm{O})}-\mathrm{O}-$ \\
$\mathrm{Mg}_{(\mathrm{O})}$ & & $\mathrm{Al}_{(\mathrm{O})}$ & $\mathrm{Mg}_{(\mathrm{O})}$ & $\mathrm{Fe}_{(\mathrm{O})}$ \\
& & & $\mathrm{Mg}_{(\mathrm{O})}-\mathrm{O}-$ & $\mathrm{Mg}_{(\mathrm{O})}-\mathrm{O}_{-}$ \\
$\mathrm{Fe}_{(\mathrm{O})}$ & & & $\mathrm{Mg}_{(\mathrm{O})}$ & $\mathrm{Fe}_{(\mathrm{O})}$ \\
& & & & & $\mathrm{Fe}_{(\mathrm{O})}-\mathrm{O}-$ \\
\end{tabular}






Figure 4. Pore size distribution of the mica mineral.

$1025 \mathrm{~cm}^{-1}$ is mainly related to the $\mathrm{Si}-\mathrm{O}-\mathrm{Si}$ stretching vibration. This is because the stretching $\mathrm{Si}-\mathrm{O}$ vibration region is expected to be between $1600-700 \mathrm{~cm}^{-1}$, and the $600-300 \mathrm{~cm}^{-1}$ range exhibits the $\mathrm{Si}-\mathrm{O}$ bending vibration, which also coincides with bending vibrations of a cation-oxygen octahedron [30,34,35,37].

The infrared bands in the range of $748-471 \mathrm{~cm}^{-1}$ correspond to the $\mathrm{Al}-\mathrm{OH}$ vibration. Singha and Singh [35] showed detailed results for different $\mathrm{Al}$ ligand vibrations, namely $\mathrm{Al}-\mathrm{OH}, \mathrm{Al}-\mathrm{O}-\mathrm{Al}$ and $\mathrm{Al}-\mathrm{O}$, which vary in a range from 910 to $405 \mathrm{~cm}^{-1}$.

\section{Specific surface area (SSA) and porosity}

The specific surface area of the mica mineral used in this study was $5.41 \mathrm{~m}^{2} \mathrm{~g}^{-1}$. Regarding the total porous volume, the result found was $0.0087 \mathrm{~cm}^{3} \mathrm{~g}^{-1}$. This parameters have a wide range of results found in literature and varies a lot depending on the mineral nature, however the results obtained are reasonably comparable to that described for micas minerals $[8,38,39]$.

The porous size distribution graphic at Figure 4 shows its gradual increase during the analysis. However the average pore size is predominantly at $40 \AA$, which is classified in the mesopore group (20-500 $\AA$ ), according to the IUPAC classification [40].

The surface area and porosity (pore structure and the pore size distribution) are important parameters that describe the mineral textural properties and they directly influence the efficiency and selectivity extent of the ionic species on adsorption process [39,41,42].

In order to enhance the adsorbent quality on this matter and provide higher adsorption results, the chemical surface modification is quite used nowadays through many techniques, such as: pillaring, acid activation, thermal treatment, polymer addition and different types of surfactants coating [4,43-45].
Gil et al. [41] demonstrated a significant increase of the specific surface area and pore volume of natural montmorillonite mineral through the pillaring process. The intercalation of aluminium and zirconium hydroxypolycations into the mineral structure produced a specific surface area almost thirty times and forty times higher, respectively, than the natural mineral presented before the treatment. Such improvements on these physical parameters of the adsorbent were clearly reflected on the dye adsorption capacities tested, namely Orange II and Methylene Blue dyes.

\section{Wettability test}

The water drop was completely and instantly spread by the surface of the tablet of ground mica and any contact angle was reproduced, which characterises the studied mica as a hydrophilic material, as many authors in literature confirmed $[2,46-50]$.

However, this behaviour was observed to be different for the raw mica sheet, where the water drop was also absorbed by the surface, but when the water drop was placed on the darker spots on the surface, it showed a contact angle that ranged from $30^{\circ}$ to $48^{\circ}$, which reported a moderate hydrophobicity.

The relative oscillation of the observed results for the raw mica sheet shall be due to many factors that influences the contact angle measurements, including irregularities, roughness and surface heterogeneity of the mineral surface $[47,50]$.

The crystalline structure of the layered silicates minerals, its degrees of lattice substitution, morphology and chemical distribution generally determines the bulk wettability of them [50].

\subsection{Morphological characterisation}

The results of the morphology of the micaceous mineral characterised by transmission electron microscopy (TEM) and scanning electron microscopy (SEM) equipped with EDX analysis are shown in Figure 5 and Figure 7, respectively.

Among many of the very interesting properties of the mica family (low dielectric loss, perfect cleavage, high flexibility, physical-chemical stability at high voltages and temperature), the most peculiar feature of the mica group, which is shown in Figure 5 through the TEM images and that demand further attention, is their distinct layered or plate-like crystal structure. Such special structure provides many possible applications in the chemical field, such as being a suitable substrate material for molecular studies or as a template to produce the active layer for solar cells. Because of the atomically flat surface, muscovite mica has been used 


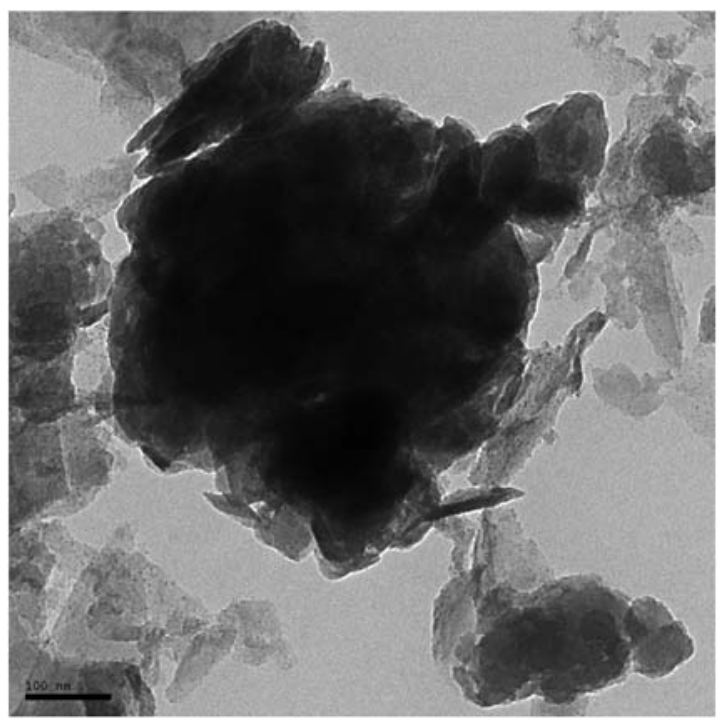

Figure 5. TEM micrographs of grounded mica mineral.

as a matrix for graphene image processing with success $[6,28,29,32,35]$.

The mica mineral sheets are initially electrically neutral and held together by weak van der Waals forces. However, when the sheet sparkles and

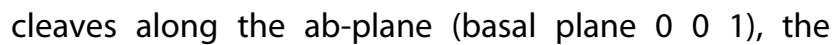
charge development occurs, independent of the $\mathrm{pH}$ of the solution, by lattice defects (vacancies or substitution) or incongruent dissolution. The interlayer cations eventually become exposed and can be replaced by various monovalent or divalent cations, which is called cation exchangeable capacity (CEC). Moreover, they are also surrounded by water molecules which define the hydration degree of the mineral as a function of the partial vapour pressure. While the edge surface of the mineral that suffered rupture of covalent or ionic bonds exhibits a strong $\mathrm{pH}$ dependence and $\mathrm{H}^{+}$and $\mathrm{OH}^{-}$are potential determining ions $[13,17,36,51,52]$.

In Figure 6, the muscovite crystal chemistry model structure is shown.
From the SEM images in Figure 7(a) and (b), it is possible to verify a structure with a rough surface. The irregularities seen are derived from the ultrasonic process applied as the preparation procedure for the scanning process.

Micro-jets of tiny bubbles with a lifetime of about 0.1 $\mu s$ produce a high impact force (about $110 \mathrm{~m} / \mathrm{s}$ ) on the mineral surface. When the bubbles collide with the surface, it produces a local high temperature and high pressure making the interlayer space increase and the mica crystallinity decrease, becoming rough. The intensity of the surface modification depends on the frequency applied to the ultrasonic waves $[27,30]$.

Liu et al. [30] investigated the effect of ultrasonic pretreatment on mica powders in order to remove the impurities and roughen the surface. The cavitation mechanism increases the bonding strength of the plating layer and the interlayer spacing for nano-nickel activation and finally for copper plating.

\subsection{Electrostatic surface properties}

Once colloidal mineral particles are immersed in a solution, a series of chemical and complex mechanisms start to simultaneously occur on the particle-water interface namely: dissolution, precipitation, adsorption, hydrolysis and cation/anion exchange reactions. Thus, the distribution of ions surrounding the electrical double layer of the minerals particles initiates the surface charge formation process. This is well stated by the DLVO theory created by Derjaguin and Landau [53] and Verwey and Overbeek [54], where the van der Waals attraction forces and electrostatic interactions are the main mechanisms acting on the system. The quantitative degree and rate at which the near-surface chemistry of the particle is influenced by the release of ionic species on the aqueous phase needs to be understood $[17,20,51,55]$.

To access and evaluate the electrical surface of silicate and multi-oxide mineral particles in this context, such as

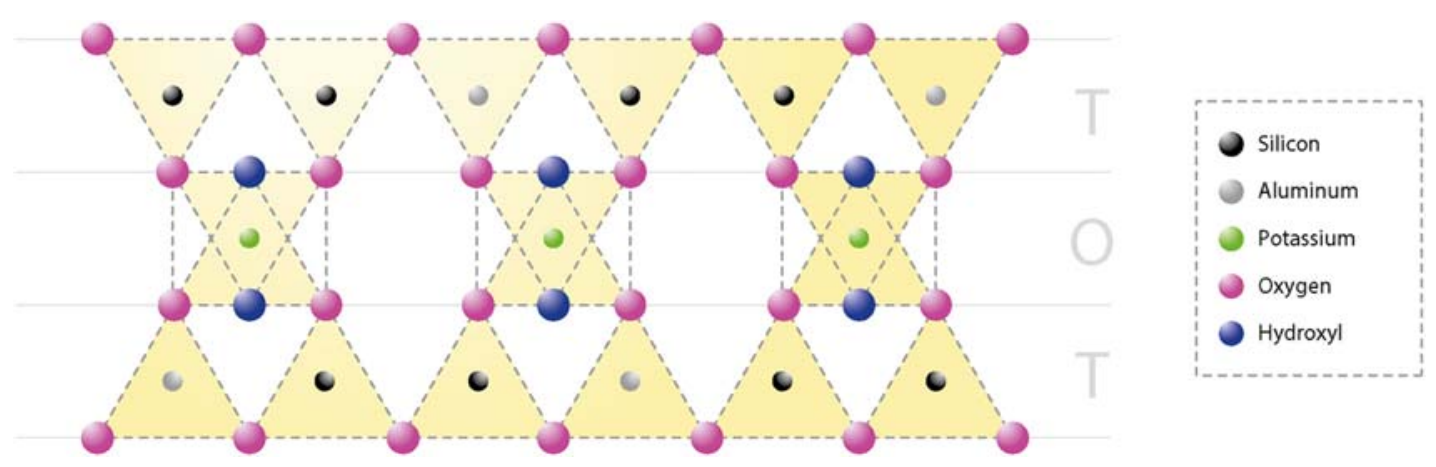

Figure 6. Crystal chemistry of muscovite mineral. Adapted from: [36]. 

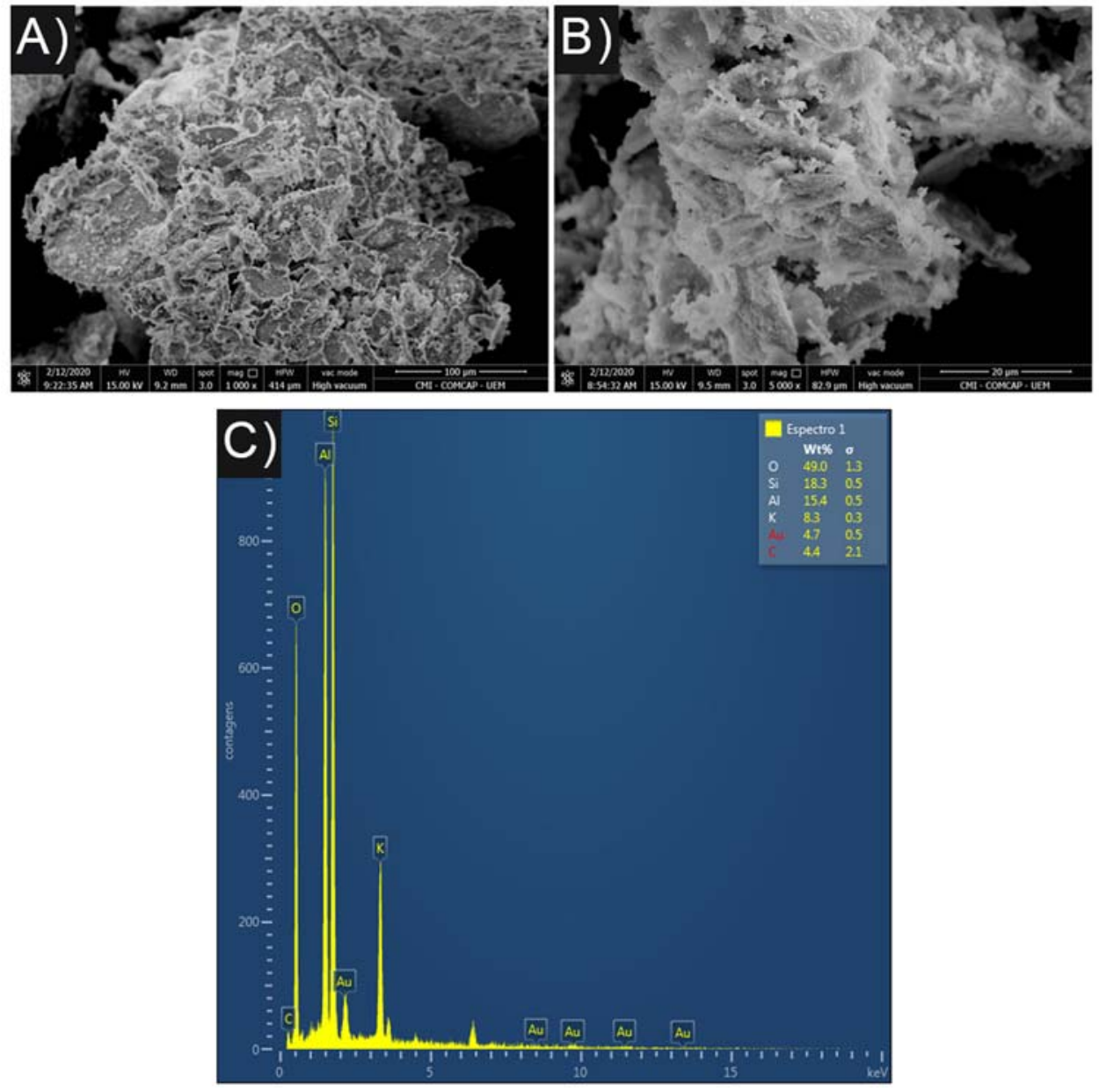

Figure 7. SEM micrographs of grounded mica mineral (a) $1000 \times$ of magnitude, (b) $5000 \times$ of magnitude, (c) EDX analysis.

the mica family, the characterisation must include both reactive surfaces: basal and edge, which have different features as discussed above. The drift method may infer the charge behaviour on the edge surface of the mineral, since the basal plane charge requires AFM measurements to determine. Precisely, the results obtained from the drift method just may partially correspond to the edge surface, if the initial protons quantities were not measured in the beginning of the trial. Having this in account, the interpretation of such data is still an important tool to guide the complex investigation journey about the mica mineral colloidal electrical behaviour. However, it is reasonable to consider that this definition may be ambiguous if the terms are not described. [18,20,26,51,56].

Among many parameters that affect the charge properties on the surface, the $\mathrm{pH}$ of the solution is considered a major interfacial variable that governs this whole scenario in the background $[18,20]$.

In order to help the prediction of the electrical behaviour of the colloidal surfaces in solution, the concept of point of zero charge has become a fundamental key indicator to improve the chemical adsorption models, for example, since it was presented in 1952 until nowadays. The general definition of point of zero charge $\left(\mathrm{pH}_{\mathrm{PzC}}\right)$ contemplates a reference state where the surface charge and the electrokinetic properties of the colloidal particles (phyllosilicate minerals) are totally equilibrated and equal to zero.

\section{Point of Zero Charge determination}

The results of $\mathrm{pH}$ measurement in the $\mathrm{pH}_{\mathrm{PzC}}$ determination trials are presented in Table 5.

Table 5. Results of final $\mathrm{pH}$ values obtained from the drift method trials.

\begin{tabular}{lcc}
\hline Initial $\mathrm{pH}$ & Final $\mathrm{pH}$ & $\Delta \mathrm{pH}$ \\
\hline 2.02 & 3.93 & 1.87 \\
3.02 & 7.46 & 4.39 \\
4.01 & 8.26 & 4.35 \\
5.01 & 8.29 & 3.34 \\
6.03 & 8.38 & 2.64 \\
7.00 & 8.55 & 1.66 \\
8.03 & 8.88 & 0.68 \\
9.02 & 8.96 & -0.25 \\
10.00 & 9.19 & -0.93 \\
\hline
\end{tabular}






Figure 8. $\mathrm{pH}$ variation between final and initial $\mathrm{pH}$ measurements of the mica mineral.

The $\mathrm{pH}_{\mathrm{PzC}}$ value was obtained from the correlation of the differences between the initial and final measured $\mathrm{pH}$, which was performed on $\Delta \mathrm{pH}$. Then, $\Delta \mathrm{pH}$ was plotted versus the initial $\mathrm{pH}$, as observed in Figure 8.

After $24 \mathrm{~h}$ of shaking the samples, the final $\mathrm{pH}$ measured showed a strong equilibrium tendency between the range from 4 to 9 . However, the observed point where the edge surface exhibits no charge is $\mathrm{pH}_{\mathrm{PZC}}=8.6$ for the mica mineral analysed.

According to the literature, such results may infer that when pHsolution $<8.6\left(\mathrm{pH}_{\mathrm{PZC}}\right)$ the mica edge surface tends to exhibit a positively charged and when pHsolution $>8.6\left(\mathrm{pH}_{\mathrm{PZC}}\right)$ the edge surface tends to present negative charge.

The $\mathrm{pH}_{\mathrm{PZC}}$ corresponds to the charge stability of the edge crystal plane of the surface, which suffered the rupture of covalent or ionic bonds and exhibits a strong $\mathrm{pH}$ dependence when charges can be formed by direct $\mathrm{H}^{+}$and $\mathrm{OH}^{-}$transfer from aqueous solution to the mica surface.

As pointed out, such preliminary results may conduct the departure point to reveal the complex electrical behaviour of mica minerals. Further investigation, should consider the ionic species dissolved during the reaction and the basal electrical behaviour through the AFM measurements [17,26,51,56,57] (Figure 9).

Even though the result obtained only from the $\mathrm{pH}_{\mathrm{PZC}}$ requires more accuracy, it has on its own a substantial value because it allows highlighting the $\mathrm{pH}$ range where the surface becomes an anion exchanger or cation exchanger. Such information is very pertinent for many reasons, for instance to manipulate the favourable conditions for the adsorption process of some pollutants or to understand the natural conditions which influence the mineral dissolution rates and consequently the contamination of the groundwater $[17,20,56]$.

The breakdown of weak chemical bonds, namely van der Waals forces, exposes the aluminol, silanol and acid hydroxide groups along the crystal edges. Hence, the edge surfaces have been demonstrated to have greater reactivity (300 times more) when compared to the basal surface $[8,13]$.

\section{Zeta potential}

The zeta potential measurement was realised from $\mathrm{pH} 2$ to 12 , and the results are represented in Figure 10.

The results show that at very acid conditions $(\mathrm{pH} \sim 2)$, the zeta potential of the mica is positive. However, shortly thereafter it meets the isoelectric point $\left(\mathrm{pH}_{\mathrm{IEP}}\right)$ around $\mathrm{pH} \mathrm{3}$, where the zeta potential is zero. After this point, the zeta potential is permanently negative, reaching the maximum value between $\mathrm{pH} 8$ and 10 .



(a) $\mathrm{pH}<\mathrm{pzc}$ Anion exchanger (b) $\mathrm{pH}=\mathrm{pzc}$ Neutral specie (c) $\mathrm{pH}>\mathrm{pzc}$ Cation exchanger
Figure 9. Representation of the mineral surface according to the $\mathrm{pH}_{\mathrm{PZC}}$ reference value. Adapted from [26]. 


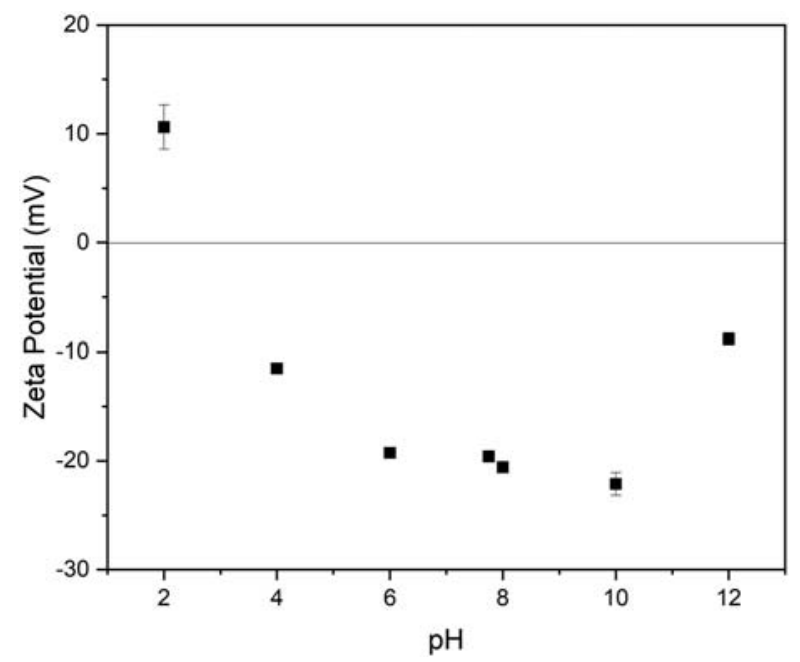

Figure 10. Zeta potential measurements results of the mica mineral.

Ideally, both approaches described should coincide and portray the statement $\mathrm{pH}_{\mathrm{PZC}}=\mathrm{pH}_{\mathrm{ZNPC}}=\mathrm{pH}_{\text {IEP. }}$. Nonetheless, according to the literature data, for some natural minerals, such as the mica family, some factual details will lead to different observation values $\left(\mathrm{pH}_{\mathrm{PzC}} \neq\right.$ $\mathrm{pH}_{\text {IEP) }}$ obtained from both experimental methods, such as surface impurities, lattice structure and mineral dissolution $[6,17,20,56]$.

The anisotropic structure of mica minerals is another important feature to consider because it gives them two different electric surfaces. The cleavage performed on the crystals produces two types of surfaces: the basal plane ( $\left.\begin{array}{lll}0 & 0 & 1\end{array}\right)$, which is the result of parallel cleavage of the layers conducting to a permanent negative charge, being $\mathrm{pH}$-independent; and the edge plane ( $h k 0)$, produced by perpendicular cleavage to the basal surface, which implies that the edge surface chemistry varies as a function of the $\mathrm{pH}$ of the surrounding aqueous phase $[8,13]$.

The electrophoretic technique does not take into consideration that the mica mineral possesses two surface types due to its anisotropic crystal structure, and that is why the zeta potential value is an average of both planes (basal and edge). On the other hand, atomic force microscopy is one path to deepen into this aspect because it allows to make measurements on isolated planes [17].

As a rule, it is well known that the basal face has a permanent negative charge due to the isomorphic substitutions of lattice elements, such as the replacement of $\mathrm{Si}^{4+}$ for $\mathrm{Al}^{3+}[6,13]$.

Moreover, Xian et al. [58] showed a method to quantify the isomorphous substitution area by atomic force microscopy (AFM) images on the mica surface because cations can be adsorbed on the selectivity sites available through electrostatic interactions.
Xu et al. [13] investigated muscovite mica for adsorption proposal, and through the electrophoretic technique obtained a $\mathrm{pH}_{\mathrm{IEP}}$ of 1.3.

Britz [6] characterised some minerals including muscovite mica in a comprehensive approach to study the interaction and interrelation of surface charge, surface complexation and transport processes. The acid-base titration result of muscovite found after $5 \mathrm{~h}$ of equilibrium, independent of the initial $\mathrm{pH}$, was around $\sim 8.07$, and after 7 days it was observed at $\sim 7.9$. The zeta potential was low at $\mathrm{pH} 2.4$, and it exhibited permanent negative surface charge above this point [6].

Bray et al. [20] investigated the biotite surface chemistry as a function of aqueous fluid composition and performed potentiometric titration trials associated with electrokinetic measurements. The equilibrium plateau was achieved at $\mathrm{pH}$ of 9.66 , but this approach was combined with a theoretical calculation that includes the net number of protons consumed by the sum of other exchange reactions, and the calculated $\mathrm{pH}_{\mathrm{ZNPC}}$ was 7.50. The electrokinetic measurements showed that the $\mathrm{pH}_{\text {IEP }}$ was 3.02 where the zeta potential is zero.

Many authors have also successfully tested the micaceous mineral applicability as an adsorbent for water pollutants, which requires an extensive characterisation of the parameters involved in the adsorption reactions as well as the electric surface charge properties of the mica particles when it is immersed in the aqueous phase. To improve the efficiency results about this application, it is indispensable to construct an accurate chemistry surface model that includes its chemical, physical and electrical characterisation [8].

Aiming towards improving the electrical surface charge understanding of many mica minerals addressed for adsorption purposes, the determination of the point of zero charge is essential, even though the experimental methods provide the approximate behaviour of the surface electrical charge of the micaceous minerals. The combined approach of chemical and morphological analyses, potentiometric titration trials and electrokinetic measurements demonstrated in this study focus on describing the chemical and electrical properties of the mica mineral in order to provide an insight into the interaction of protons on the edge surfaces of the mica. Nonetheless, it is important to make clear that complementary analyses are definitely required to support the experimental potential shortcomings.

\subsection{Batch adsorption experiments}

Table 6 shows the results of the adsorption tests for both studied dyes (SO and RB5) and includes its final 
Table 6. Adsorption tests results of Safranin Orange (SO) and Reactive Black 5 (RB5) on mica mineral.

\begin{tabular}{|c|c|c|c|c|c|c|}
\hline \multirow[b]{2}{*}{$\mathrm{pH}$} & \multicolumn{3}{|c|}{$\begin{array}{c}\text { Safranin Orange }(\mathrm{SO}) \mathrm{C}_{\mathrm{i}}(\mathrm{OS})= \\
10.02 \mathrm{mg} \mathrm{L}^{-1}\end{array}$} & \multicolumn{3}{|c|}{$\begin{array}{l}\text { Reactive Black } 5(\mathrm{RB} 5) \mathrm{C}_{\mathrm{i}}(\mathrm{OS})= \\
11.49 \mathrm{mg} \mathrm{L}^{-1}\end{array}$} \\
\hline & $\begin{array}{l}\mathrm{C}_{\mathrm{f}}(\mathrm{OS}) \\
\mathrm{mg} \mathrm{L}^{-1}\end{array}$ & $\begin{array}{l}\mathrm{q}_{\mathrm{e}}(\mathrm{OS}) \\
\mathrm{mg} \mathrm{g}^{-1}\end{array}$ & $\begin{array}{l}\% \text { removal } \\
(\mathrm{OS})\end{array}$ & $\begin{array}{l}\mathrm{C}_{\mathrm{f}}(\mathrm{RB} 5) \\
\mathrm{mg} \mathrm{L}^{-1}\end{array}$ & $\begin{array}{l}\mathrm{q}_{\mathrm{e}} \text { (RB5) } \\
\mathrm{mg} \mathrm{g}^{-1}\end{array}$ & $\begin{array}{l}\text { \% removal } \\
\text { (RB5) }\end{array}$ \\
\hline 3 & 7 & 1.10 & 27.40 & 630 & 2.08 & 45.17 \\
\hline 5 & & & & & & 7.01 \\
\hline 7 & & & & & & 6 \\
\hline 9 & 1.715 & 3.32 & 82.88 & 9.49 & 0.44 & 9.49 \\
\hline
\end{tabular}

concentration $\left(C_{f}\right)$, adsorption capacity $\left(q_{\mathrm{e}}\right)$ and removal efficiency.

The SO adsorption capacity demonstrated to have a much better performance on mica surface in opposition with $\mathrm{RB} 5$ dye, especially in the $\mathrm{pH}$ range above 5 . The higher adsorption capacity of $\mathrm{SO}$ was observed at $\mathrm{pH} 9$ and achieved almost $83 \%$ of removal. This behaviour was expected since the zero net point charge $\left(\mathrm{pH}_{\mathrm{ZNPC}}\right)$ predicted that on the $\mathrm{pH}$ range over 8.59, the mica surface would be negatively charged. In this case, the main mechanism identified that drove this result is the electrostatic force of attraction between the adsorbent surface (negative) and the pollutant dyes particles (positive). Adebowale et al. [59] also investigated the SO adsorption by kaolinite clay mineral and observed a removal result of $88,8 \%$ on the $\mathrm{pH}$ range of 9 and 10 .

Moreover, the literature underlines that cationic dye, which is the case of SO, has a comparatively higher adsorption capacity than anionic dyes, like RB5, on clay minerals. Another interesting point to highlight is that even dyes with the same ionic charge, the adsorption capacity cannot be the same because of the difference of its molecular structure, triangular or linear molecular structure for instance. $[4,42,44]$.

Analogously, the RB5 dye adsorption on mica surface had the highest result, about $45 \%$ of removal, on $\mathrm{pH}$ of 3. This is also may due to the attraction forces between the positive charge of the mica surface and the negative charge of the anionic dyes (RB5). In a comprehensive review about different materials used in RB5 adsorption, Sarvestani and Doroudi [60] also reported that acid solutions usually are the best conditions to enhance the adsorption capacity. The chitosan-based adsorbents are the most used material for RB5 adsorption and have shown the highest percentage removal of RB5 amongst the other ones, however, the material presents low mechanical and structural stability in acid conditions, which is a crucial feature for such anionic dye removal.

Figure 11 shows the adsorption capacity of both dyes according to the $\mathrm{pH}$ variation.

Clearly, the ionic nature of each dye had a huge influence over the results. At acid conditions, the

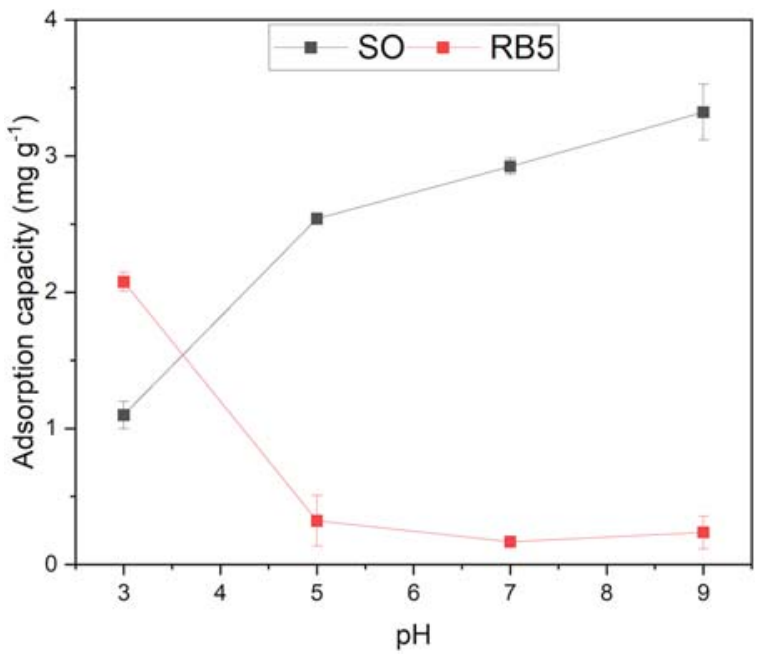

Figure 11. Adsorption tests results for Safranin Orange (SO) and Reactive Black 5 (RB5).

presence of $\mathrm{H}^{+}$ions in solution may lead to a competition for the adsorption site into the mineral surface with the cationic dye (SO). Whilst, the lower adsorption capacity of the anionic dye (RB5) at basic conditions could be attributed to the excess of $\mathrm{OH}^{-}$ions that compete for the same adsorption sites $[60,61]$.

\section{Conclusion}

The physical-chemical and morphological characterisation through the transmission electron microscopy images showed that the mica mineral has the major chemical elements (oxygen, aluminium, potassium) arranged in a layered structure with atomically flat surface. However, the scanning electron microscopy images demonstrated that the mica mineral surface becomes rough after the ultrasonic pretreatment was applied. Such physical modification is very interesting from the adsorption point of view because it breaks down some chemical bonds, increasing the interlayer space, which may improve the adsorption probabilities.

As a preliminary study, we focus on the variation of the $\mathrm{pH}$ parameter because it is the most important variable that influences the electrostatic properties, since both materials (adsorbent-mica mineral and adsorbatedye particles) are electrically charged. The results showed promising adsorption efficiency especially for Safranin Orange (SO) with around $82 \%$ of removal from an aqueous solution with $\mathrm{pH}$ 9. While the Reactive Black 5 (RB5) achieved its maximum efficiency removal at $45 \%$ at $\mathrm{pH} 3$. The assessment of the electrostatic surface properties through the determination of the Point of Zero Charge $\left(\mathrm{pH}_{\mathrm{PzC}}\right)$ and zeta potential measurements were a useful tool on this research 
because we may indicate that the electrostatic interactions mechanisms drove partially the adsorption mechanisms and gave a great contribution to the potential of mica minerals on such field. Moreover, the mineral surface chemistry can be activated through chemical or physical pretreatments in order to improve the anionic pollutants adsorption efficiency. And then, an interesting point would be an adsorption experiment that includes both anionic and cationic pollutants particles in an aqueous solution.

The raw grounded mica mineral has a greater potential associated with its application on cationic dye removal in wastewater, in this case Safranin Orange.

Studies about thermodynamic properties of the system through isotherms adjustment, kinetics, activation energy, change of Gibbs free energy, enthalpy and entropy of both dyes (SO and RB5) adsorption experiments are also necessary in future studies because they look for to modelling the occurring reactions to achieve better results.

The surface chemical modifications are also an alternative to boost the mica mineral adsorption capacity. However, the great value shown in this study is that the mica mineral used had passed through no chemical pre-treatment, which is a huge gain for the economical feasibility of this eco-friendly adsorbent.

The main characteristics of the mica mineral were presented, in order to highlight the complex electrical behaviour, mainly of its edge surface, and demonstrate its applicability as an eco-friendly pollutants adsorbent for water contaminants and effluents.

For future works, deep analyses are expected, such as aqueous analysis of the dissolved species present during the drift methods trials and atomic force microscopy (AFM) of the mica mineral. Granulometric studies are also suggested in the literature, because the grain size can contribute to increasing the surface area.

\section{Data availability statement}

The data that support the findings of this study are available from the corresponding author, Ribeiro, A.C., upon reasonable request.

\section{Disclosure statement}

No potential conflict of interest was reported by the author(s).

\section{ORCID}

Heloise Beatriz Quesada (D) http://orcid.org/0000-0003-37623079

\section{References}

[1] Ali I, Asim M, Khan TA. Low cost adsorbents for the removal of organic pollutants from wastewater. J Environ Manage. 2012;113:170-183.

[2] Zhou Y, Lu J, Zhou Y, et al. Recent advances for dyes removal using novel adsorbents: a review. Environ Pollut. 2019;252:352-365. doi:10.1016/j.envpol.2019.05.072.

[3] Crini G. Non-conventional low-cost adsorbents for dye removal: a review. Bioresour Technol. 2006;97(9):10611085.

[4] Shahadat M, Isamil S. Regeneration performance of claybased adsorbents for the removal of industrial dyes: a review. RSC Adv. 2018;8(43):24571-24587. doi:10.1039/ C8RA04290J.

[5] Abukhadra MR, El-Meligy MA, El-Sherbeeny AM. Evaluation and characterization of Egyptian ferruginous kaolinite as adsorbent and heterogeneous catalyst for effective removal of safranin-O cationic dye from water. Arabian J Geosci. 2020;13(4):169, doi:10.1007/s12517020-5182-6.

[6] Britz, S. M. Europium sorption experiments with muscovite, orthoclase, and quartz: Modeling of surface complexation and reactive transport. Doctoral dissertation, Technische Universität Carolo-Wilhelmina zu Braunschweig. 2018.

[7] Ceolin LPW, Junior TRA, Morais MM, et al. Biotite (black mica) as an adsorbent of pesticides in aqueous solution. Water Air Soil Pollut. 2015;226(8):1-9. doi:10.1007/ s11270-015-2489-0.

[8] Chakraborty S, Wolthers M, Chatterjee D, et al. Adsorption of arsenite and arsenate onto muscovite and biotite mica. J Colloid Interface Sci. 2007;309(2):392-401. doi:10.1016/j. jcis.2006.10.014.

[9] Hebert J, Wang L, Wang X, et al. Mechanisms of safranin O interaction with 1:1 layered clay minerals. Sep Sci Technol. 2020: 1-11. doi:10.1080/01496395.2020.1806325.

[10] Mustapha S, Ndamitso MM, Abdulkareem AS, et al. Application of $\mathrm{TiO}_{2}$ and $\mathrm{ZnO}$ nanoparticles immobilized on clay in wastewater treatment: a review. Appl Water Sci. 2020;10(1):1-36. doi:10.1007/s13201-019-1138-y.

[11] Sieren B, Baker J, Wang X, et al. Sorptive removal of color dye safranin $\mathrm{O}$ by fibrous clay minerals and zeolites. Adv Mater Sci Eng. 2020, doi:10.1155/2020/8845366.

[12] Su L, Chen J, Ruan H, et al. Characterization of modified mineral waste material adsorbent as affected by thermal treatment for optimizing its adsorption of lead and methyl orange. Am Mineral. 2020;105(9):1392-1403.

[13] $\mathrm{Xu} \mathrm{L}, \mathrm{Wu} \mathrm{H}$, Dong F, et al. Flotation and adsorption of mixed cationic/anionic collectors on muscovite mica. Miner Eng. 2013;41:41-45. doi:10.1016/j.mineng.2012. 10.015.

[14] Yang JS, Lee JY, Park YT, et al. Adsorption of As (III), As (V), $\mathrm{Cd}$ (II), $\mathrm{Cu}$ (II), and $\mathrm{Pb}$ (II) from aqueous solutions by natural muscovite. Sep Sci Technol. 2010;45(6):814-823.

[15] Fanning D, Keramidas V, Micas E-DM. Minerals in soil environments. Madison: Soil Science Society of America; 1989. p. 551-634. doi:10.2136/sssabookser1.2ed.c12.

[16] Brindley GW, Brown G. Crystal structures of clay minerals and their X-ray identification. London: Mineralogical Society of Great Britain and Ireland; 1980; 495 p. doi:10.1180/mono-5. 
[17] Alvarez-Silva M, Mirnezami M, Uribe-Salas A, et al. Point of zero charge, isoelectric point and aggregation of phyllosilicate minerals. Can Metall Q. 2010;49(4):405-410.

[18] Sposito G. On points of zero charge. Environ Sci Technol. 1998;32(19):2815-2819. doi:10.1021/es9802347.

[19] Ames LL, Mcgarrah JE, Walker BA. Sorption of uranium and radium by biotite, muscovite, and phlogopite. Clays Clay Miner. 1983;31(5):343-351.

[20] Bray AW, Benning LG, Bonneville S, et al. Biotite surface chemistry as a function of aqueous fluid composition. Geochim Cosmochim Acta. 2014;128:58-70.

[21] Pavlovic M, Rouster P, Oncsik T, et al. Tuning colloidal stability of layered double hydroxides: from monovalent ions to polyelectrolytes. ChemPlusChem. 2017;82 (1):121-131. doi:10.1002/cplu.201600295.

[22] Yu YW, Zhao HT, Vance GF. Removal of arsenite from aqueous solutions by anionic clays. Environ Technol. 2001;22(12):1447-1457. doi:10.1080/09593330.2001. 11090879.

[23] Meena VS, Maurya BR, Verma JP, et al. Potassium solubilizing rhizobacteria (KSR): isolation, identification, and Krelease dynamics from waste mica. Ecol Eng. 2015;81:340-347. doi:10.1016/j.ecoleng.2015.04.065.

[24] Basak BB, Biswas DR. Influence of potassium solubilizing microorganism (Bacillus mucilaginosus) and waste mica on potassium uptake dynamics by Sudan grass (Sorghum vulgare Pers.) grown under two alfisols. Plant Soil. 2009;317(1-2):235-255.

[25] Balouch A, Kolachi M, Talpur FN, et al. Sorption kinetics, isotherm and thermodynamic modeling of defluoridation of ground water using natural adsorbents. Amer J Analytical Chem. 2013;4(5):221-228.

[26] Khan MN, Sarwar A. Determination of points of zero charge of natural and treated adsorbents. Surf Rev Lett. 2007;4(3):461-469. doi:10.1142/S02186210.5277/ ppmp1701165X07009517.

[27] Jena SK, Dash N, Rath SS. Effective utilization of lime mud for the recovery of potash from mica scraps. J Clean Prod. 2019;231:64-76. doi:10.1016/j.jclepro.2019.05.231.

[28] Tarefder R, Faisal H, Sobien H. Nanomechanical characterization effect of mica and aging on asphalt binder. J Mater Civ Eng. 2014;26(9):04014063. doi:10.1061/ (ASCE)MT.1943-5533.0000962.

[29] Zhang J, Soltani A, Deng A, et al. Mechanical behavior of micaceous clays. J Rock Mech Geotech Eng. 2019;11 (5):1044-1054. doi:10.1016/j.jrmge.2019.04.001.

[30] Liu W, Qiao X, Liu S, et al. A new process for pre-treatment of electroless copper plating on the surface of mica powders with ultrasonic and nano-nickel. J Alloys Compd. 2019;791:613-620. doi:10.1016/j.jallcom.2019. 03.360 .

[31] Aylmore MG, Merigot K, Quadir Z, et al. Applications of advanced analytical and mass spectrometry techniques to the characterisation of micaceous lithium-bearing ores. Miner Eng. 2018;116:182-195. doi:10.1016/j. mineng.2017.08.004.

[32] Poel W, Pintea S, Drnec J, et al. Muscovite mica: flatter than a pancake. Surf Sci. 2014;619:19-24. doi:10.1016/j. susc.2013.10.008.

[33] Bray AW, Oelkers EH, Bonneville $\mathrm{S}$, et al. The effect of $\mathrm{pH}$, grain size and organic ligands on biotite weathering rates. Geochim Cosmochim Acta. 2015;128:127-145.
[34] Matterson A, Herron MM. Quantitative mineral analysis by Fourier transform infrared spectroscopy. SCA Conference Paper. 1993;9308:1-16.

[35] Singha $M$, Singh L. Vibrational spectroscopic study of muscovite and biotite layered phyllosilicates. Indian J Pure Appl Phys. 2016;54:116-122.

[36] Kurganskaya I, Luttge A. A comprehensive stochastic model of phyllosilicate dissolution: structure and kinematics of etch pits formed on muscovite basal face. Geochim Cosmochim Acta. 2013;120:545-560. doi:10. 1016/j.gca.2013.06.038.

[37] Piccinini M, Cibin G, Marcelli A, et al. Synchrotron radiation FTIR micro-spectroscopy of natural layer-silicates in the $\mathrm{O}-\mathrm{H}$ stretching region. Infrared Phys Technol. 2006;49(1-2):64-68. doi:10.1016/j.infrared.2006.01. 014.

[38] Abukhadra MR, Mostafa M. Effective decontamination of phosphate and ammonium utilizing novel muscovite/ phillipsite composite; equilibrium investigation and realistic application. Sci Total Environ. 2019;667:101-111. doi:10.1016/j.scitotenv.2019.02.362.

[39] Bentaleb K, Bouberka Z, Chinoune K, et al. Enhanced adsorption of 2,4-dichlorophenol from aqueous solution using modified low cost Algerian geomaterial. J Taiwan Inst Chem Eng. 2017;80:578-588.

[40] Rouquerol J, Avnir D, Fairbridge CW, et al. Recommendations for the characterization of porous solids (technical report). Pure Appl Chem. 1994;66 (8):1739.

[41] Gil A, Assis FCC, Albeniz S, et al. Removal of dyes from wastewaters by adsorption on pillared clays. Chem Eng J. 2011;168(3):1032-1040.

[42] Ngulube T, Gumbo JR, Masindi V, et al. An update on synthetic dyes adsorption onto clay based minerals: a stateof-art review. J Environ Manage. 2017;191:35-57. doi:10. 1016/j.jenvman.2016.12.031.

[43] Bhattacharyya KG, Gupta SS. Adsorption of a few heavy metals on natural and modified kaolinite and montmorillonite: a review. Adv Colloid Interface Sci. 2008;140 (2):114-131

[44] Kausar A, lqbal M, Javed A, et al. Dyes adsorption using clay and modified clay: A review. J Mol Liq. 2018;256:395-407. doi:10.1016/j.molliq.2018.02.034.

[45] Tetteh S, Quashie A, Anang MA. Purification, characterization, and time-dependent adsorption studies of Ghanaian muscovite clay. J Chem. 2018;2018; doi:10. 1155/2018/6252913.

[46] Jiang H, Gao Y, Khoso A, et al. A new approach for characterization of hydrophobization mechanisms of surfactants on muscovite surface. Sep Purif Technol. 2019;209:936-945. doi:10.1016/j.seppur.2018.09.023.

[47] Kowalczuk PB, Akkaya C, Ergun M, et al. Water contact angle on corresponding surfaces of freshly fractured fluorite, calcite and mica. Physicochem Problems Mineral Process. 2017;53; doi:10.5277/ppmp170116.

[48] Maximova N, Österberg M, Laine J, et al. The wetting properties and morphology of lignin adsorbed on cellulose fibres and mica. Colloids Surf A. 2004;239(1-3):6575. doi:10.1016/j.colsurfa.2004.01.015.

[49] Van Oss CJ, Giese RF. The hydrophilicity and hydrophobicity of clay minerals. Clays Clay Miner. 1995;43(4):474477. doi:10.1346/CCMN.1995.0430411. 
[50] Yin X, Gupta V, Du H, et al. Surface charge and wetting characteristics of layered silicate minerals. Adv Colloid Interface Sci. 2012;179:43-50. doi:10.1016/j.cis.2012.06.004.

[51] Liu J, Miller JD, Yin X, et al. Influence of ionic strength on the surface charge and interaction of layered silicate particles. J Colloid Interface Sci. 2014;432:270-277. doi:10. 1016/j.jcis.2014.06.028.

[52] Rama M, Eklund O, Frojdo S, et al. Characterization of altered mica from Sokli, Northern Finland. Clays Clay Miner. 2020: 1-11. doi:10.1007/s42860-019-00041-0.

[53] Derjaguin B, Landau L. Theory of the stability of strongly charged lyophobic sols and of the adhesion of strongly charged particles in solutions of electrolytes. Prog Surf Sci. 1941;43(1-4):30-59.

[54] Verwey EJW, Overbeek JTG. Theory of the stability of lyophobic colloids. Amsterdam: Elsevier; 1948.

[55] Van Oss CJ, Giese RF, Constanzo PM. DLVO and non-DLVO interactions in hectorite. Clays Clay Miner. 1990;38 (2):151-159. doi:10.1346/CCMN.1990.0380206.

[56] Hao W, Flynn SL, Alessi DS, et al. Change of the point of zero net proton charge $\left(\mathrm{pH}_{\mathrm{PZNPC}}\right)$ of clay minerals with ionic strength. Chem Geol. 2018;493:458-467. doi:10. 1016/j.chemgeo.2018.06.023.

[57] Errais E, Duplay J, Darragi F, et al. Efficient anionic dye adsorption on natural untreated clay: kinetic study and thermodynamic parameters. Desalination. 2011;275(1-3):74-81.

[58] Xian Z, Hao Y, Zhao Y, et al. Quantitative determination of isomorphous substitutions on clay mineral surfaces through AFM imaging: a case of mica. Colloids Surf A. 2017;533:55-60. doi:10.1016/j.colsurfa.2017.08.024.

[59] Adebowale KO, Olu-Owolabi BI, Chigbundu EC. Removal of safranin-O from aqueous solution by adsorption onto kaolinite clay. J Encapsul Adsorp Sci. 2014;4(03):89), doi:10.4236/jeas.2014.43010.

[60] Sarvestani MRJ, Doroudi Z. Removal of reactive black 5 from waste waters by adsorption: a comprehensive review. J Water Environ Nanotechnol. 2020;5(2):180190. doi:10.22090/JWENT.2020.02.008.

[61] Elmoubarki R, Mahjoubi FZ, Tounsadi H, et al. Adsorption of textile dyes on raw and decanted Moroccan clays: kinetics, equilibrium and thermodynamics. Water Resour Industry. 2015;9:16-29. 